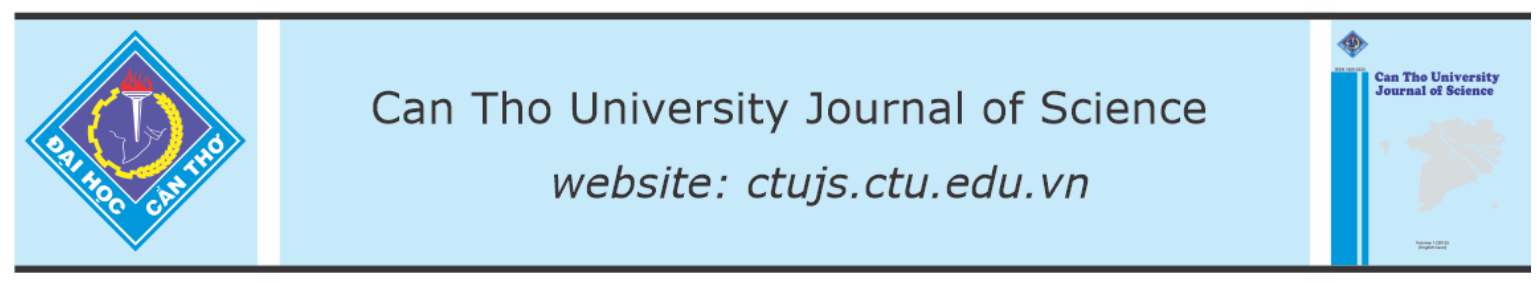

DOI: 10.22144/ctu.jen.2021.034

\title{
Growth and survival performance of G2 crossbreeds from two strains of bighead catfish (Clarias macrocephalus)
}

\author{
Dedan Karanja Njihia ${ }^{1}$ and Duong Thuy Yen ${ }^{2 *}$ \\ ${ }^{1}$ International Master Program in Aquaculture, Course 3 (2018-2020), Can Tho University, Viet Nam \\ ${ }^{2}$ College of Aquaculture and Fisheries, Can Tho University, Viet Nam \\ *Correspondence: Duong Thuy Yen (email: thuyyen@ctu.edu.vn)
}

\section{Article info.}

Received 22 Aug 2020

Revised 31 Jan 2021

Accepted 20 Nov 2021

\section{Keywords}

Bighead catfish,

crossbreeding, genetic improvement, growth, larval rearing

\begin{abstract}
The development of bighead catfish (Clarias macrocephalus) aquaculture in Viet Nam has been constrained by the slow growth performance in the domesticated strain. Crossbreeding can be a solution to improve fish production. This study was aimed to evaluate the growth and survival performance of the second generation (G2) fingerlings crossbreeds (CMCT and CTCM) from two bighead catfish strains (wild Ca Mau, CM, and domesticated Can Tho, CT) compared to offspring from their original strains (G0-CT and G0-CM) and G1 crossbreeds ( 9 CM $\times \hat{\mathrm{O}} \mathrm{CT}$ and $\bigcirc \mathrm{CT}$ $\times \widehat{\jmath} C M$ ). The larvae were reared in 50-L tanks (3 to 5 replications) with the density of 1,000 individuals/tank and fed with Moina and artificial feed (40\% protein). After 40 days of rearing, the fish grew differently among crosses $(P<0.05)$. In which, the two best-growth groups included $C M \times C T$ crossbreeds (body weight of $1,114 \mathrm{mg}$ and length of $4.55 \mathrm{~cm}$ ) and pure crossbred line CTCM (1,050 $\mathrm{mg}$ and $4.51 \mathrm{~cm}$, respectively). The CTCM group was recorded the highest survival rate (37.8\%) while G0-CT was the lowest (27.2\%); however, the difference in survival was not significant $(P>0.05)$. The performance of these crossbreeds should be investigated further at the grow-out stage to see whether crossbreeding between wild and cultured strains of bighead catfish may be used in practice to increase bighead catfish production.
\end{abstract}

\section{INTRODUCTION}

Catfishes in the genus Clarias are widely distributed in subtropical and tropical areas of Asia and Africa (Teugels \& Adriaens, 2003). In Viet Nam for instance, Clarias catfish is one of the commercially important aquaculture fish groups consisting of $C$. macrocephalus, $C$. gariepinus, $C$. fuscus, $C$. batrachus, and one hybrid C. macrocephalus $(\mathrm{Cm})$ x C. gariepinus ( $\mathrm{Cg}$ ) (Lenonnand et al., 1998). Among the four Clarias species, bighead catfish ( $C$. macrocephalus) is a popular species with a high economic value (Hien et al., 2018). It has long been an important target for aquaculture in Southeast Asia (Carreon et al., 1976; Na-Nakorn et al., 1995).

Bighead catfish is however not so popular in intensive farming due to low disease resistance and a slow growth rate (FAO, 2010). While its hybrid catfish $(\mathrm{Cm} \times \mathrm{Cg})$ that exhibits fast growth rate, high tolerances to environmental conditions, and resistance to diseases has been cultured in many provinces in Viet Nam (Duong et al., 2017). Native bighead catfish remains to be the most preferred 
choice by consumers amongst the Clarias catfishes because of its better flesh quality. Therefore, bighead catfish has higher market prices compared to the hybrid catfish.

To cope with the above drawbacks, genetic improvement of the native bighead catfish through crossbreeding of different populations is a potential choice. In which, intraspecific crossbreeding often increases the growth rate of aquaculture species, although specific heterotic combinations need to be experimentally identified (Hulata, 2001). It also has the advantage of simplicity and the often immediate and visible impact on animal performance. Various intraspecific crossbreeding cases have been reported (Dunham, 2011). For example, the Vietnamese $\times$ Hungarian common carp has fast growth and high survival rates under different production conditions and for this reason, the crossbreed is very popular in both the northern and southern regions of Viet Nam (Thien \& Trong, 1995). Similarly, crosses of six different strains of silver barbs in Viet Nam have shown heterosis for growth rate (Bentsen et al., 1996).

In this study, the survival, and growth performances of crossbreeds created through intra-specific crossbreeding across two generations of $C$. macrocephalus were investigated. The findings for this undertaking would shed light on the possibilities of improving the growth performance of bighead catfish through intraspecific crossbreeding.

\section{MATERIALS AND METHODS}

\subsection{Source of broodstock}

The original broodstock (called G0) of $C$. macrocephalus adults were collected from U Minh Ha National Park in Ca Mau province (wild, CM), Lung Ngoc Hoang conservation in Hau Giang province (wild, HG) and from a hatchery in Can Tho province (cultured, CT) in March 2019. They were cultured in a recirculating system at College of Aquaculture and Fisheries (CAF) and were abbreviated as G0-CM, G0-CT, and G0-HG.

Nine diallel crosses including three pure and six reciprocal crosses $(+\mathrm{CM} \times \hat{\delta} \mathrm{CT}$, $+\mathrm{CT} \times \hat{\mathrm{CM}}$,

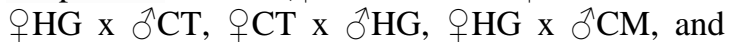
$\mathrm{CMx}{ }^{\lambda} \mathrm{HG}$ ) from the three strains were produced and evaluated their growth from May 2019 to December 2019. At the market stage, two

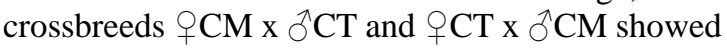
better growth performance among six crossbreeds (Duong et al., 2022) and they were chosen for the present experiment. They were marked as G1CMCT and G1-CTCM. By May 2020 these crossbreeds had become mature and 15-20\% larger adults were chosen to produce offspring (G2-CMCT and G2-CTCM). These offspring were compared with those produced by $\mathrm{G} 1$ crosses between $\mathrm{CM}$ and CT strains (G1-CM x G1-CT and their reciprocals G1-CT x G1-CM) and by two pure G0 ( $9 \mathrm{CM} \times$ $\widehat{C} \mathrm{CM}$ and $\bigcirc \mathrm{CT} \mathrm{x}(\mathrm{CT})$. In sum, six offspring treatments were evaluated in this study (Table 1).

Table 1. Experimental crosses/treatments

\begin{tabular}{|c|c|c|}
\hline Parents producing the offspring & Notes on parent conditions & Label for offspring treatments \\
\hline $+\mathrm{G} 1-\mathrm{CMCTx} \hat{\circ} \mathrm{G} 1-\mathrm{CMCT}$ & & 1. $\mathrm{CMCT}$ \\
\hline GI-CTCMx ${ }^{\top}$ G1-CTCM & These $G 1$ groups were produced & СТCM \\
\hline $+\mathrm{G} 1-\mathrm{CMx}{ }^{\hat{T}} \mathrm{G} 1-\mathrm{CT}$ & In May, 2019 and cultured in the & 3. $\mathrm{CMxCT}$ \\
\hline क G1- CTx & & 4. СТхСМ \\
\hline${ }_{+} \mathrm{G} 0-\mathrm{CMx}{ }^{\hat{T}} \mathrm{G} 0-\mathrm{CM}$ & $\mathrm{G} 0$ is the generation producing & 5. G0-CM \\
\hline${ }_{+} \mathrm{G} 0-\mathrm{CTx} \partial \hat{\mathrm{G}} 0-\mathrm{CT}$ & G1 above & 6. G0-CT \\
\hline
\end{tabular}

\subsection{Artificial propagation, fertilization and incubation}

Five to seven pairs of mature breeders from each group (Table 1) were injected with human chorionic gonadotropin hormone (HCG) and pituitary gland (PG) hormone (as described in Tran \& Duong, 2021). After the $12 \mathrm{~h}$ latency period, the milt was obtained from the testes of freshly - killed male breeders and was pooled from several individuals. Milt was mixed with eggs using dry fertilization method. Fertilized eggs were removed adhesiveness by urea solution $(3 \mathrm{~g}$ urea $+4 \mathrm{~g} \mathrm{NaCl}$ in $1 \mathrm{~L}$ of distilled water) and then $1.5 \mathrm{ppt}$ tannin solution was added for 10 seconds to remove the stickiness of the eggs. Finally, clean water was used to wash out all the chemical residues from the eggs before incubation. Incubation and hatching of eggs were carried in the jar incubating system. The water temperature in the incubator fluctuated between 28 $34^{\circ} \mathrm{C}$. 


\subsection{Design of larval rearing experiment}

The rearing system included $50-\mathrm{L}$ rectangular tanks (containing $40 \mathrm{~L}$ of water) equipped with aeration. The three-day-old larvae were pooled by each cross and randomly stocked in tanks at a density of 1000 larvae per tank. Each cross had 5 replications except for CMxCT and CTxCM which were replicated 4 and 3 times, respectively, due to the inadequate number of larvae.

The larvae were fed twice daily ( 8 a.m. \& 5 p.m.) with Moina for 10 days, starting from the 3rd day of hatching. Thereafter, commercial feed $(40 \%$ protein) was added to combine with Moina for the weaning of fry from the $9^{\text {th }}$ day to the $15^{\text {th }}$ day when they could eat $100 \%$ artificial feed. At this point, they were fed four times a day (8 a.m., 11 a.m., 2 p.m. and 5 p.m.). Uneaten artificial feed and waste were siphoned and water was exchanged 30 to $50 \%$ every day. The water temperature over the rearing period fluctuated between $26-34^{\circ} \mathrm{C}$ while the water $\mathrm{pH}$ shifted between 6.8 and 7.6.

\subsection{Sampling and data collection}

The experiment lasted for 40 days. Before stocking, 30 larvae from each cross were measured of their initial weight and length. At the middle $\left(20^{\text {th }}\right.$ day $)$ and at the end of the experiment ( $40^{\text {th }}$ day), 30 to 40 larvae from each tank were randomly sampled and recorded their weight and length. These data were used to determine the survival rate (SR) and growth performance parameters (daily weight gain, DWG; daily length gain, DLG; specific growth rate in weight, SGRW; and specific growth rate in length, SGRL) as follows:

$$
\begin{aligned}
& \text { DWG (g/day) } \\
& =\frac{\text { Final body weight }(\mathrm{g})-\text { Initial body weight }(\mathrm{g})}{\text { Rearing period in days }}
\end{aligned}
$$

$$
\begin{aligned}
& \text { DLG }(\mathrm{mm} / \text { day }) \\
& =\frac{\text { Final body length }(\mathrm{mm})-\text { Initial body length }(\mathrm{mm})}{\text { Rearing period in days }}
\end{aligned}
$$

$$
\begin{aligned}
& \text { SGRW(\%/day) } \\
& =\frac{\text { Ln final weight }- \text { Ln initial weight }}{\text { Rearing period in days }} \times 100 \\
& \text { SGRL (\%/day) } \\
& =\frac{\text { Ln final length }- \text { Ln initial lenght }}{\text { Rearing period in days }} \times 100 \\
& \text { SR }(\%)=\frac{\text { Number of survival fish }}{\text { Number of fish stocked }} \times 100
\end{aligned}
$$

Coefficients of variation (CV, \%)

$$
=\frac{\text { Standard deviation }}{\text { mean weight }} \times 100
$$

\subsection{Statistical analysis}

Survival rates and coefficient of variance were transformed to natural logarithm before statistical analysis (Warton \& Hui, 2011). These transformed data and growth parameters were compared among fish treatments using one-way analysis of variance (ANOVA), followed by Duncan's multiple range tests. The significant difference was evaluated at the level of 0.05. SPSS version 20.0 was used for statistical analysis.

\section{RESULTS}

\subsection{Growth in weight of six crosses}

The growth trend in weight of six larval groups during 40 days of experiment is shown in Figure 1. Overall, the weight of the larvae in all the treatments demonstrated an upward trajectory over the experimental period. However, the growth trend differed remarkably among fish groups as evidenced by the slope of the growth lines, especially in the last 20 days. CMxCT and CTCM exhibited best parallel growth while G0-CT, CMCT, and G0-CM demonstrated a moderate increase. Contrastingly, a slow growth line was manifested in CTxCM. 


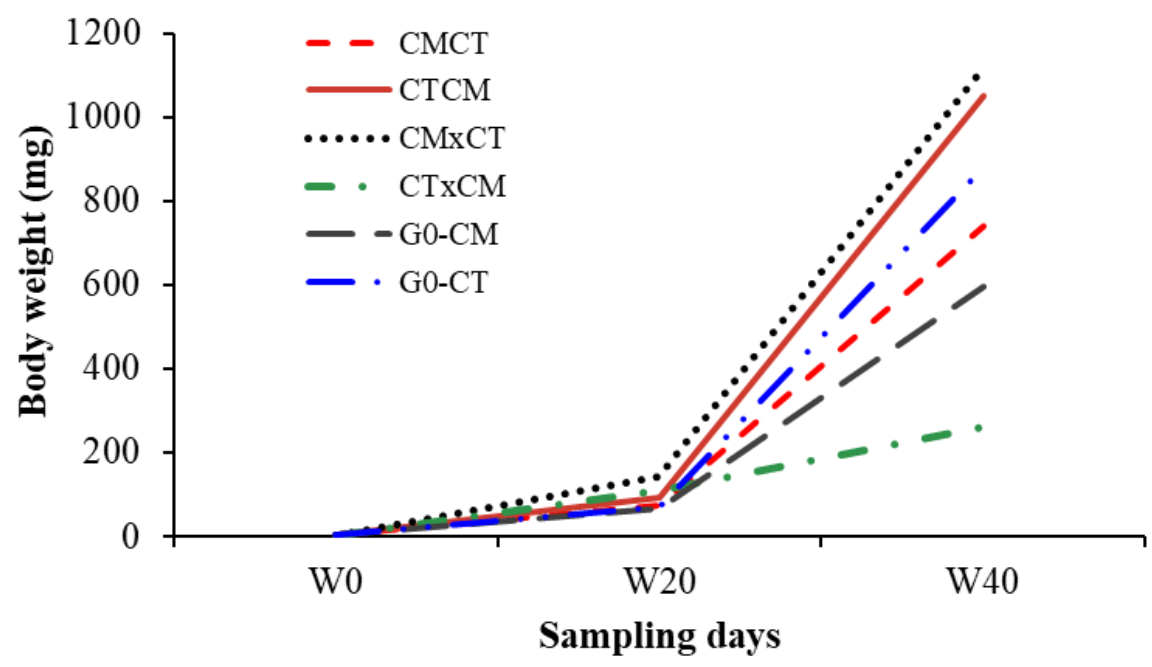

Figure 1. Larval body weight trend during 40 rearing days of six experimental crosses

Analysis of variance showed significant differences $(\mathrm{P}<0.05)$ in all growth weight parameters (Table 2). At the beginning of the experiment, the three-days old larvae weighed from 2.10 (CMxCT) to $3.24 \mathrm{mg}$ (G0-CT). CTCM was the second large fish (3.04 $\mathrm{mg}$ ), while the other groups had similar initial weights (from 2.55 to $2.72 \mathrm{mg}$ ).

Table 2. Means \pm SD of initial weight, mid-weight, final weight, daily weight gain (DWG) and specific growth rate in weight (SGRW) of the six experimental crosses

\begin{tabular}{lrrrrr}
\hline Crosses & W0 $(\mathbf{m g})$ & W20 $(\mathbf{m g})$ & W40 $(\mathbf{m g})$ & DWG $(\mathbf{m g} /$ day $)$ & SGRW $(\% /$ day $)$ \\
\hline CMCT & 2.60 & $73.7 \pm 11.5^{\mathrm{a}}$ & $740.2 \pm 139.8^{\mathrm{bc}}$ & $18.4 \pm 3.5^{\mathrm{bc}}$ & $14.1 \pm 0.4^{\mathrm{bc}}$ \\
CTCM & 3.04 & $93.4 \pm 23.0^{\mathrm{ab}}$ & $1,050 \pm 148^{\mathrm{cd}}$ & $26.2 \pm 3.7^{\mathrm{cd}}$ & $14.6 \pm 0.4^{\mathrm{cd}}$ \\
CMxCT & 2.10 & $141.8 \pm 39.6^{\mathrm{c}}$ & $1,114 \pm 353^{\mathrm{d}}$ & $27.8 \pm 8.8^{\mathrm{d}}$ & $15.6 \pm 0.8^{\mathrm{d}}$ \\
CTxCM & 2.55 & $110.7 \pm 8.3^{\mathrm{b}}$ & $262.5 \pm 77.4^{\mathrm{a}}$ & $6.5 \pm 1.9^{\mathrm{a}}$ & $11.5 \pm 0.8^{\mathrm{a}}$ \\
G1-CM & 2.72 & $67.9 \pm 15.0^{\mathrm{a}}$ & $594.1 \pm 267.1^{\mathrm{ab}}$ & $14.8 \pm 6.7^{\mathrm{b}}$ & $13.3 \pm 1.2^{\mathrm{b}}$ \\
G1-CT & 3.24 & $71.2 \pm 7.8^{\mathrm{a}}$ & $878.8 \pm 334.8^{\mathrm{bcd}}$ & $21.9 \pm 8.4^{\mathrm{bcd}}$ & $13.8 \pm 1.0^{\mathrm{bc}}$ \\
\hline
\end{tabular}

Means in the same column having the same superscript letter are not significantly different $(P>0.05)$

After 20 days of larval rearing, fish growth was significantly separated into three groups. The CMxCT group showed the highest weight $(141.8 \pm 39.6 \mathrm{mg})$, significantly different from the other groups $(\mathrm{P}<0.05)$. It was followed by its reciprocal CTxCM and CTCM (110.7 \pm 8.3 and $93.4 \pm 23.0 \mathrm{mg}$, respectively). Contrastingly, the other three groups G0-CM, G0-CT, and CMCT had the lowest weights. At the end of the experiment (40 ${ }^{\text {th }}$ day), CMxCT and CTCM groups recorded the highest weights of $1,050 \pm 148 \mathrm{mg}$ and $1,114 \pm 353$ $\mathrm{mg}$, respectively. CTxCM group did not maintain its growth trend that was observed during the midsampling, and instead, it ranked the last in the final sampling with a mean weight of $262.53 \pm 77.40 \mathrm{mg}$ (Table 2).

The daily weight gain (DWG) and the specific growth rate in weight (SGRW) among all the treatments were statistically different $(\mathrm{P}<0.05)$. CTxCM group performed exemplary well in both variables at $27.8 \pm 8.8 \mathrm{mg} /$ day and $15.6 \pm 0.8 \% /$ day, respectively. This was closely followed by CTCM $(26.2 \pm 3.7 \mathrm{mg} /$ day and $14.6 \pm 0.4 \% /$ day, respectively). The poorest DWG and SGRW was recorded in CTxCM with $6.5 \pm 1.9 \mathrm{mg} /$ day and $11.5 \pm 0.8 \% /$ day accordingly.

\subsection{Growth in length}

Figure 2 presents the trend in length gain of the larvae at three sampling periods (at the beginning, $20^{\text {th }}$ and $40^{\text {th }}$ day). Generally, the growth trend of body length was similar to that observed in the body weight, showing different slopes among fish groups and between two sampling periods. CMxCT and CTCM exhibited an outstanding length gain while on the other hand, CTxCM revealed a slow length gain. 


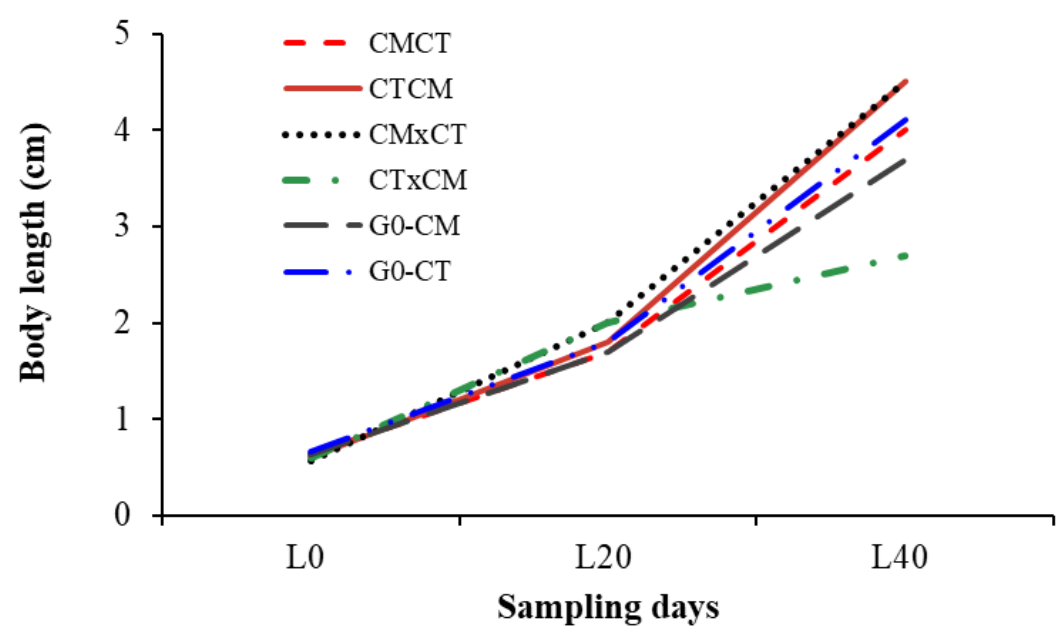

Figure 2. Larval body length trend for the six experimental crosses

In Table 3, the means for initial length (L0), midlength (L20), final length (L40), DLG, and SGRL were significantly different among fish crosses $(\mathrm{P}<0.05)$ between the crosses. Generally, the body length exhibited a similar trend of differences among treatments to that was manifested in the body weight. The highest body length at the $20^{\text {th }}$ day $(2.0 \pm 0.2 \mathrm{~cm}$ was observed in the intraspecific cross
CMxCT and its reciprocal CTxCM. Towards the end of the rearing period, CMxCT and CTCM groups had the highest body length (mean of 4.5 $\mathrm{cm}$ ), insignificantly followed by G0-CT and CMCT $(\mathrm{P}>0.05)$, while $\mathrm{G} 0-\mathrm{CM}$ had the lowest final length $(2.7 \pm 0.2 \mathrm{~cm})$. Other growth parameters including DLG and SGRL showed similar trend as that of final length.

Table 3. Initial length, mid-length, final length, daily length gain (DLG) and specific growth rate in length (SGRL) of the six experimental crosses

\begin{tabular}{lrrrrr}
\hline Cross & L0 $(\mathbf{c m})$ & L20 $(\mathbf{c m})$ & L40 $(\mathbf{c m})$ & DLG $(\mathbf{c m} /$ day $)$ & SGRL $(\% /$ day $)$ \\
\hline CMCT & $0.63 \pm 0.04^{\mathrm{bc}}$ & $1.7 \pm 0.1^{\mathrm{a}}$ & $4.0 \pm 0.2^{\mathrm{bc}}$ & $0.10 \pm 0.01^{\mathrm{bc}}$ & $4.6 \pm 0.2^{\mathrm{bc}}$ \\
CTCM & $0.61 \pm 0.03^{\mathrm{b}}$ & $1.8 \pm 0.2^{\mathrm{ab}}$ & $4.5 \pm 0.3^{\mathrm{c}}$ & $0.10 \pm 0.01^{\mathrm{c}}$ & $5.0 \pm 0.2^{\mathrm{cd}}$ \\
CMxCT & $0.57 \pm 0.04^{\mathrm{a}}$ & $2.0 \pm 0.2^{\mathrm{b}}$ & $4.5 \pm 0.6^{\mathrm{c}}$ & $0.10 \pm 0.01^{\mathrm{c}}$ & $5.2 \pm 0.3^{\mathrm{c}}$ \\
CTxCM & $0.58 \pm 0.03^{\mathrm{a}}$ & $2.0 \pm 0.0^{\mathrm{b}}$ & $2.7 \pm 0.2^{\mathrm{a}}$ & $0.05 \pm 0.00^{\mathrm{a}}$ & $3.9 \pm 0.2^{\mathrm{a}}$ \\
G0-CM & $0.64 \pm 0.02^{\mathrm{cd}}$ & $1.7 \pm 0.2^{\mathrm{a}}$ & $3.7 \pm 0.7^{\mathrm{b}}$ & $0.08 \pm 0.02^{\mathrm{b}}$ & $4.3 \pm 0.5^{\mathrm{b}}$ \\
G0-CT & $0.66 \pm 0.02^{\mathrm{d}}$ & $1.8 \pm 0.1^{\mathrm{ab}}$ & $4.1 \pm 0.6^{\mathrm{bc}}$ & $0.09 \pm 0.01^{\mathrm{bc}}$ & $4.6 \pm 0.3^{\mathrm{bc}}$ \\
\hline
\end{tabular}

"Means in the same column having the same superscript letter are not significantly different $(P>0.05)$

\subsection{Survival rates and growth differentiation}

There was no significant difference $(\mathrm{P}>0.05)$ in the survival rates among fish treatments, ranging from $27.2 \%$ (G0-CT) to $37.8 \%$ (CTCM) (Table 4).

Bighead catfish in all treatments showed high variation in individual growth. The higher the coefficient of variance (CV) in the body weight and length indicated a higher level of heterogeneity in sizes. Coefficient of variance in weight determined at the end of the larval rearing experiment (Table 4) was much higher (ranging between $60.8 \%$ and $94.6 \%)$ compared to $\mathrm{CV}$ in length (21.7-26.7\%). The CTxCM cross showed the highest CVs (94.69 $\pm 9.5 \%$ in weight and $26.7 \pm 1.5 \%$ in length) whereas CTCM was recorded the least values $(55.8 \pm 14.3 \%$ and $20.3 \pm 3.4 \%$, respectively). However, differences in CV were not significant in weight $(\mathrm{P}>0.05)$ but in length $(\mathrm{P}<0.05)$. 
Table 4. Coefficients of variation $(\mathrm{CV})$ and survival rates in the six treatments

\begin{tabular}{lrrr}
\hline Treatment & CV in weight (\%) & CV in length (\%) & Survival rate (\%) \\
\hline CMCT & $60.8 \pm 11.4^{\mathrm{a}}$ & $21.7 \pm 2.6^{\mathrm{a}}$ & $35.6 \pm 10.2^{\mathrm{a}}$ \\
CTCM & $55.8 \pm 14.3^{\mathrm{a}}$ & $20.3 \pm 3.4^{\mathrm{a}}$ & $37.8 \pm 2.9^{\mathrm{a}}$ \\
CMxCT & $70.5 \pm 24.2^{\mathrm{a}}$ & $24.5 \pm 4.0^{\mathrm{ab}}$ & $28.1 \pm 11.9^{\mathrm{a}}$ \\
CTxCM & $94.6 \pm 9.5^{\mathrm{a}}$ & $26.7 \pm 1.5^{\mathrm{b}}$ & $34.4 \pm 3.0^{\mathrm{a}}$ \\
G0-CM & $88.3 \pm 51.3^{\mathrm{a}}$ & $23.3 \pm 3.3^{\mathrm{ab}}$ & $38.3 \pm 9.8^{\mathrm{a}}$ \\
G0-CT & $71.3 \pm 18.1^{\mathrm{a}}$ & $23.0 \pm 3.0^{\mathrm{ab}}$ & $27.2 \pm 5.5^{\mathrm{a}}$ \\
\hline
\end{tabular}

"Means in the same column having the same superscript letter are not significantly different $(P>0.05)$.

The distribution of final weight values within and between fish treatments is shown in Figure 3. The highest ratios were distributed between 0.3 and $2.0 \mathrm{~g}$.
The frequencies of the weight values between treatments didn't conform to the common trend.

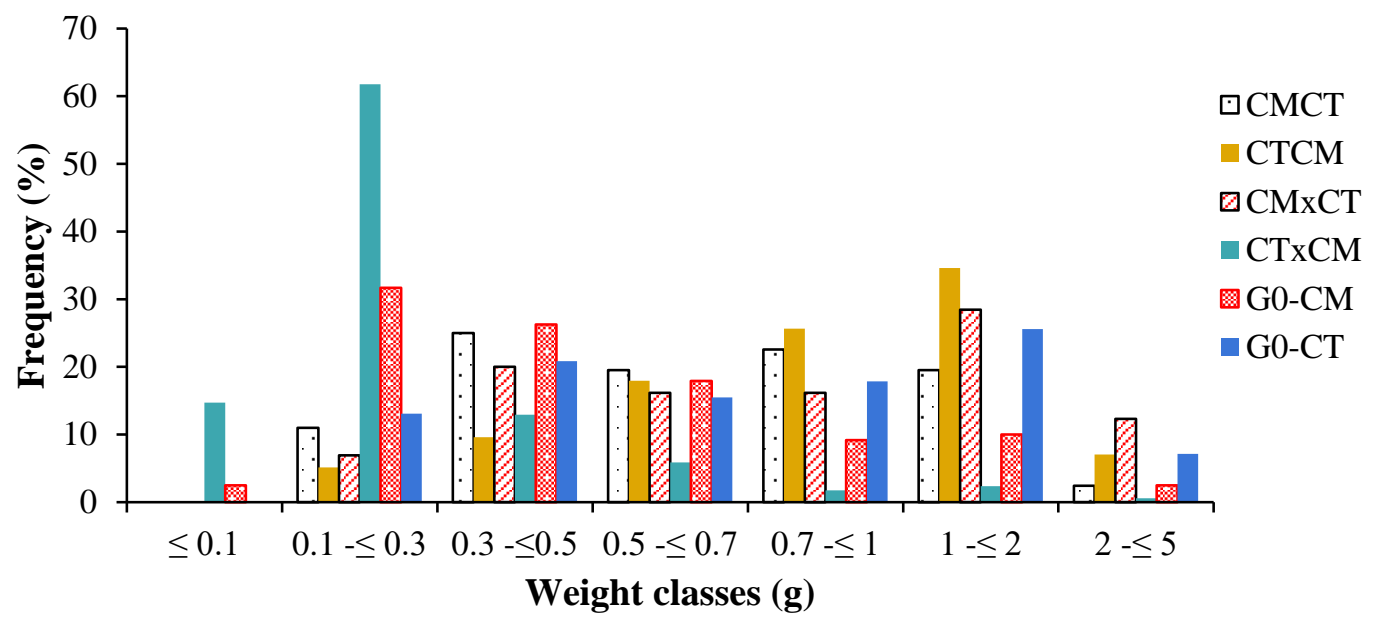

Figure 3. Growth differentiation of the larvae among the treatments on the $40^{\text {th }}$ day

In the CTxCM and G0-CM groups, the frequencies dropped gradually from small to large sizes, with the highest ratio being recorded in the weight class of 0.1 to $0.3 \mathrm{~g}$ ( $61 \%$ and $29 \%$, respectively) and the lowest in the class of 2.0 to $5.0 \mathrm{~g}$. An opposite tendency was recorded in the CTCM cross, whereby the rate of the observation raised steadily from small to large weight classes. The frequencies in CMCT, $\mathrm{CMxCT}$, and G0-CT cross oscillated between low and high within the range between 0.3 and $5.0 \mathrm{~g}$.

\section{DISCUSSION}

The present study confirmed that G2 of CTxCM crossbreed (CTCM) exhibited over-performance compared to other crosses. They had a significantly faster growth rate, (insignificantly) higher survival rate and lower heterogeneity (lower CVs) than the other groups. Growth rate is considered a trait of great economic importance for all species used in aquaculture, and thus it is a trait of interest for most breeding programs (Tave, 1993; Dunham, 2011). The results of this study show that crossbreeding between bighead catfish strains can produce better growth of progenies.

In other studies, crossbreeding between wild broodstock strains (CM, HG or Long An, LA) and a cultured strain in $\mathrm{CT}$ showed that the reciprocal crossbreeds CMxCT and CTxCM had better growth performance than other crossbreeds (Duong et al., 2020; Duong et al., 2022). Similar results were observed in the present study when CMxCT crossbred had the highest growth rate. Differently, its reciprocal CTxCM grew fast at first but was stunted in the later stage. It is common that the performance of reciprocal crossbreds can be different due to maternal effects (R. A. Dunham \& Smitherman, 1983). More importantly, this study indicated that $\mathrm{CMxCT}$ crossbred can be used for grow-out (when CMxCT had better growth) and/or used as breeders when their offspring (CMCT and CTCM) exhibited outstanding performance compared to the original pure sources CM and CT. 
Survival is among the most important traits determining production capacity in aquaculture. From the results of this study, the survival rates among all mating combinations were not different (Table 4). The outcomes of the study also indicated that the survival rates were relatively low in all treatments (ranging from 27 to 38\%). The low survival could in part be linked to cannibalism due to uniformity in the larvae sizes (Figure 3). Clarias catfish are known for their cannibalistic behavior especially in their young stage in the case of $C$. macrocephalus. Legendre et al. (1992) suggested that size segregation is necessary for Clariid catfish culture to avoid cannibalism. In this study, size segregation was not done which might have increased the chances of cannibalism consequently resulting in poor survival performance. Similarly, Opiyo et al. (2017) reported a low survival rate of $23.28 \%$ in African catfish, which was linked to heterogeneity in sizes (high value of the coefficient of variation, $\mathrm{CV}$ ), consequently resulting in cannibalism. In this study the $\mathrm{CV}$ in weight was high, ranging between 60.8 and $94.6 \%$, thus confirming that indeed cannibalism contributed to the poor survival performance. Another possible factor pointing out to the low survival could be management and handling stress. Iwalewa et al. (2017) found the performance of $C$. gariepinus fingerlings in an intraspecific study to be associated with good management and adequate feeding. The daily siphoning of uneaten feed from the tanks

\section{REFERENCES}

Bentsen, H. B., Godrem, T., \& Nguyen, V. H. (1996). Breeding plan for silver barb (Puntius gonionotus) in Vietnam: individual (mass) selection to improve growth rate. The International Network on Genetics in Aquaculture (INGA) Report No. 3. https://hdl.handle.net/20.500.12348/2748

Carreon, J. A., Estocapio, F. A., \& Enderez, E. M. (1976). Recommended procedures for induced spawning and fingerling production of Clarias macrocephalus Gunther. Aquaculture, 8(3), 269281. https://doi.org/10.1016/0044-8486(76)90089-2

Dunham, R. (2011). Aquaculture and fisheries biotechnology: genetic approaches (2nd ed.). CABI Publishing.

Dunham, R. A., \& Smitherman, R. O. (1983). Crossbreeding channel catfish for improvement of body weight in earthen ponds. Growth, 47(1), 97-103.

Duong, T.Y., Nguyen, V. C., \& Duong, N. L. (2017). Development history of hybrid catfish farming and the perception of farmers on hybrid issues. Can Tho University Journal of Science, 50(B), 91-96. followed by partial daily water exchange may have caused stress to the larvae and eventually leading to fatalities.

\section{CONCLUSION AND RECOMMENDATIONS}

G2 pure crosses of CTCM and CMCT and crossbred $\mathrm{CMx}(\mathrm{CT})$ generated from wild $(\mathrm{CM})$ and cultured (CT) strains strains of bighead catfish showed the outstanding growth and survival at the fingerling stage.

The performance of the experimental crosses used in the study should be continuously evaluated in the grow-out stage to come up with a factual answer to whether crossbreeding between wild and cultured strains of bighead catfish can be applied in practice to improve production of bighead catfish. The good performance of CTCM and CMCT can be further maximized by applying selection in further generations.

\section{ACKNOWLEDGMENTS}

This study is funded by the Can Tho University Improvement Project VN14-P6, supported by a Japanese ODA loan. Our special thanks are sent to our colleagues and students, working in Department of Freshwater Aquaculture, College of Aquaculture and Fisheries, for their technical support during this experiment including but not limited to fish propagation and larval sampling.

Duong, T. Y., Tuan, N. T., Nghia, N. Van, \& Pha, D. T. (2020). Growth of bighead catfish (Clarias macrocephalus) fingerlings crossbred from three broodstock sources. Can Tho University Journal of Science, 56(2), 102-109.

Duong, T. Y., Nguyen, T. N. T., Nguyen, T. T., Huynh, T. T. L., Bui, M. T., Pham, T. L., \& Dunham, R. (2022). Growth and survival of crossbreeds between wild and domestic strains of Mekong Delta bighead catfish (Clarias macrocephalus Günther, 1864) cultured in tanks. Aquaculture, 547, 737507. https://doi.org/10.1016/J.AQUACULTURE.2021.737507

FAO. (2010). Fishstat Plus Version 2.30. (Available source: http://www.fao.org/fi/statist/ FISOFT/FISHPLUS.asp, December 17, 2012).

Hien, T. T. T., Tuan, L., Tu, T. L. C., \& Tam, B. M. (2018). Dietary protein requirement of bighead catfish (Clarias macrocephalus Gunther, 1864) fingerling. International Journal of Scientific and Research Publications (IJSRP), 8(11), 4-10. https://doi.org/10.29322/ijsrp.8.11.2018.p8326

Hulata, G. (2001). Genetic manipulations in aquaculture: A review of stock improvement by classical and 
modern technologies. Genetica, 111(1-3), 155-173. https://doi.org/10.1023/A:1013776931796

Iwalewa, M., Akinwale, Adewole, M. ., Okhiria, E., Ebonwu, B., Iheanacho, E. ., \& Bede, O. C. (2017). Improving breeding performance of fingerlings of Clarias gariepinus through intraspecific hybridization. Agronomie Africaine, 29(2), 109-114.

Legendre, M., Teugels, G. G., Cauty, C., \& Jalabert, B. (1992). A comparative study on morphology, growth rate and reproduction of Clarias gariepinus (Burchell, 1822), Heterobranchus longifilis Valenciennes, 1840, and their reciprocal hybrids (Pisces, Clariidae). Journal of Fish Biology, 40, 5979. https://doi.org/10.1111/j.10958649.1992.tb02554.X

Lenonnand, S., Slembrouck, J., Pouyaud, L., Subagja, J., \& Legendre, M. (1998). Evaluation of hybridisation in five Clarias species (Silurlformes, clarlidae) of African (C. gariepinus) and Asian origin ( $C$. batrachus, C. meladerma, $C$. nieuhofji and $C$. tejjsmanni). Proceedings of the Mid-Term Workshop of the "Catfish Asia Project"-The Biological Diversity and Aquaculture of Clariid and Pangasiid Catfishes in South-East Asia., 195-209.

Na-Nakorn, U., Chantsawang, S., \& Tarnchalanukit, W. (1995). Response to mass selection for disease resistance in walking catfish, Clarias macrocephalus. Journal of Applied Aquaculture, 4(65-74), 65-74.

https://doi.org/10.1300/J028v04n04_06
Opiyo, M. A. (2017). Fecundity, growth parameters and survival rate of three african catfish (Clarias gariepinus) strains under hatchery conditions. Journal of Aquaculture Engineering and Fisheries Research, 3(2), 75-81. https://doi.org/10.3153/jaefr17010

Tave, D. (1993). Genetics for Fish Hatchery Managers ( $2^{\text {nd }}$ ed.). Van Nostrand Reinhold New York.

Teugels, G. G., \& Adriaens, D. (2003). Taxonomy and Phylogeny of Clariidae: An Overview. In G. Arratia, B. G. Kapoor, M. Chardon, \& R. Diogo (Eds.), Catfishes (pp. 465-487). Science Publishers, Inc., Enfield, NH USA and Plymouth, UK. https://www.academia.edu/304453/Taxonomy_and_ Phylogeny_of_Clariidae_An_Overview

Thien, T. M., \& Trong, T. D. (1995). Genetic resources of common carp in Vietnam. Aquaculture, 129(1-4), 216-216. https://doi.org/10.1016/00448486(95)91963-v

Tran, Q. C., \& Duong, T. Y. (2021). Reproductive parameters and larval growth of bighead catfish (Clarias macrocephalus Günther, 1864) from wild and cultured broodstock strains. Vietnam Journal of Agricultural Sciences, 4(3). Retrieved from https://vjas.vnua.edu.vn/index.php?journal=vjas\&pa ge=article\&op=view \&path[]=309

Warton, D. I., \& Hui, F. K. C. (2011). The arcsine is asinine: The analysis of proportions in ecology. Ecology, 92(1), 3-10. https://doi.org/10.1890/100340.1 